University of Nebraska - Lincoln

DigitalCommons@University of Nebraska - Lincoln

1976

\title{
A System and Program for Monitoring CO2 Concentration Gradient, and Flux in an Agricultural Region
}

N. J. Rosenberg

S. B. Verma

University of Nebraska - Lincoln

Follow this and additional works at: https://digitalcommons.unl.edu/natrespapers

Part of the Natural Resources and Conservation Commons, Natural Resources Management and Policy Commons, and the Other Environmental Sciences Commons

Rosenberg, N. J. and Verma, S. B., "A System and Program for Monitoring CO2 Concentration Gradient, and Flux in an Agricultural Region" (1976). Papers in Natural Resources. 1187.

https://digitalcommons.unl.edu/natrespapers/1187

This Article is brought to you for free and open access by the Natural Resources, School of at DigitalCommons@University of Nebraska - Lincoln. It has been accepted for inclusion in Papers in Natural Resources by an authorized administrator of DigitalCommons@University of Nebraska - Lincoln. 


\author{
Reprinted from Agronomy Journal \\ Vol. 68, March-April 1976, p. 414-418 \\ American Society of Agronomy, 677 S. Segoe Rd., Madison, WI 53711
}

\title{
A System and Program for Monitoring $\mathrm{CO}_{2}$ Concentration, Gradient, and Flux in an Agricultural Region \\ Norman J. Rosenberg and Shashi B. Verma
}




\title{
A System and Program for Monitoring $\mathrm{CO}_{2}$ Concentration, Gradient, and Flux in an Agricultural Region ${ }^{1}$
}

\author{
Norman J. Rosenberg and Shashi B. Verma ${ }^{2}$
}

\begin{abstract}
Because of the changing global concentration of carbon dioxide and the possible effects of this change on photosynthetic activity worldwide, a program has been de. veloped for monitoring atmospheric carbon dioxide concentration and gradients representative of a large agri cultural region. The program is carried out at Mead, Neb. A meteorological tower is equipped with sampling intakes at various clevations up to $16 \mathrm{~m}$, through which air is drawn to the laboratory for analysis with infra-red gas analyzers. An automatic calibration system has been developed to permit hourly checks of analyzer performance. Profiles of wind speed and air temperature are also measured. The equipment, the calibration techniques, and the errors associated with the measurements of $\mathrm{CO}_{2}$ concentration and gradients are described. Some initial observations of $\mathrm{CO}_{\#}$ concentrations and fluxes are presented.
\end{abstract}

Additional index words: $\mathrm{CO}_{2}$ profile, Infra-red gas analyzers, Automatic calibration, Field-photosynthesis, Turbulent transfer, Mass transfer, Micrometeorology.

$\mathrm{T}$ HERE is need for detailed experimental data so as to better estimate the source and sink strengths for atmosplieric $\mathrm{CO}_{2}$ exerted by terrestrial vegetated surfaces and the buffering effect which these surfaces exert on the global concentration. In a report to the United Nations Conference on the Human Environment (Stockholm, 1972), the Commission on Monitoring, Scientific Committee on Problems of the Environment, International Council of Scientific Unions recommended that atmospheric carbon dioxide concentration and flux data be collected at reference stations world-wide for assessing secular changes of the global climate. In view (in fact, in anticipation) of this, an organized program to regularly observe and analyze patterns in $\mathrm{CO}_{2}$ concentration and gradients at a well instrumented rural site has been initiated at one of the Univ. of Nebraska's Agricultural Meteorology laboratories (Mead, Neb.).

In this paper, we describe our measuring and calibration techniques as well as the errors involved in $\mathrm{CO}_{2}$ analysis. Brown and Rosenberg (1968) proposed certain technical improvements in $\mathrm{CO}_{2}$ sampling and analysis for field photosynthesis research. They also analyzed the errors in estimating photosynthetic fluxes caused by errors in measurement of $\mathrm{CO}_{2}$ concentration and other factors. In this paper we describe further

'Published as Paper No. 3829, Journal Series, the Neb. Agric. Exp. Stin. The work reported was conducted under Neb. Agric. Exp. Stn. Project No. 20-31 and Regional Research Project No. 11.33. Received 10 July 1975.

- Professor and assistant professor, Agricultural Metcorology Section, Dep. of Agricultural Enginecring, Institule of Agriculture and Natural Resources, Viniv, of Nebratska, Lincolin, NE 68583 .

"Based on 59 manometric standards (Dr. C. D. Kecling, Scripps Institution of Oceanograplay, Univ. of Cillifornia, Sim Diego.
personal communications, 1975). technical refinements and improvements which make the routine observation of $\mathrm{CO}_{2}$ concentration and gradients reliable. Our system functions in a gencral micrometeorological research facility where other, fre. quently unrelated, experiments are conducted concus. rently. Some initial observations are presented.

\section{METHODS AND MATERIALS}

$C O$, Sampling and Analysis System. A $19.2 \mathrm{~m}$ meteorological tower at Mead, Neb. (41. $09^{\prime} \mathrm{N} ; 96^{\circ} 30^{\prime} \mathrm{W}$; altitude $35 \mathrm{I}^{\circ}$ above m.s.I.) is equipped with sampling intakes through which air is drawn into a laboratory building about $60 \mathrm{~m}$ away for measurement of $\mathrm{CO}_{2}$ concentration and gradients. The totat analytical system is described in a schematic given as Appentix 1. Component specifications are given in $\AA_{\text {ppendix }} 11$. The system has capacity to sample air at eight locations or eleva. tions. Individual diaphragm pumps, located near the tower (1)ut external to the laboratory), are used for each sample line, These pumps draw air under vacuun and move it into and through the aboratory under positive pressure.

The sample lines terminate in the laboratory building at individual rotameters where flow rate into the mixing chamber is controlled. Air from each separate level is continuously mixed in 7.6 liter (2 gal.) cylinders to smooth out the rapid fluctuation in $\mathrm{CO}_{2}$ concentration. Periodically (usually every 15 min) ait samples are drawn in sequence from the mixing cylinders through the infra-red gas analyzers (IRGA). Air from the highest elesa. tion sampled (level 1) is passed through a Beckman model 315.1 to determine the absolute concentration of $\mathrm{CO}_{\mathrm{z}}$. Then air from the same source (level 1) is passed through one side of a Beckman IRG.1 molel 315B, used as a differential analyaer, fom comparison with air originating at the next lowest level (level 2 ). The concentration difference between wo samples is deternimed in this way. In the next step air from level 3 is drawn through the differential analyzer replacing the sample from level 1. Then the concentration difference between levels 2 atud 3 is determined. This process is repeated until all necessiry con parisons are made. The electrical output signal of the gas analyzers is recorded with an analogue to digital conversion meteorological data logging system housed in the laboratory.

Calibration Procedures. I sistem has been developed to pes mit automatic hourly calibration of both IRCiAs. Nnalyes ou put data during calibration rums is also recorded by the dat. logging system. The calibration system works in the following wity. Once each hour an upscale standard gas of kumsn (i) concentration is passed through the absolute IRG.t and the analyzer response is recorded. Then a downscale gas is suh stituted. At the same time a single standard gas is passed through both sides of the differential IRGA. Zero concenti. tion should be indicated by the IRGA when this is done. I la response, whether zero or not, is recorded. Then (wo different standard gases of known concentrations (differing by it suit able working range) are passed through the two chambers ot the differential IRG.A to record an upseale response. With the IRC $A$ responses measured and recorded during a catibration cycle, the drift of the analyzers can be monitored and the fieth observations can be adjusted for changing IRCA calibrations

A comparison of standard gases of the sane nominal concen. tration, but supplied by different manufacturers, convinced us of the need for an independent calibration of our standard gass Our primary standard gases atre calibrated to an accaracs of \pm 0.3 to $0.5 \mathrm{ppm}$ by the lir Resources Laboratory of X(i) il in Boulder, Colorato:. Our secondary standards are calibrated against these primary gases by differential gas analssis. 1 lot secondary standards are used in the automatic analyee calilis tion procedure described above. 
Errors in $\mathrm{CO}_{2}$. Analysis. It was found that even small pressure differences between the reference and sample sides of the dif. ferential IRGA resulted in measurable imbalances and that the error was increased with greater concentration of $\mathrm{CO}_{2}$ in the sample gas. Concentration difference errors in the order of 1 ppm were possible. Such errors can produce serious bias in the cal. culation of $\mathrm{CO}_{2}$ fluxes.

The problem of pressure imbalance has been elininated by use of precise pressure regulation devices and flow meters. It is now possible to maintain the pressure differences between the analyzer tubes at $0 \pm 1.0 \mathrm{mb}$. These pressure differences are monitored periodically with a water manometer to detect any failures in pressure regulation.

Because the absorption bands of $\mathrm{CO}_{2}$ and $\mathrm{H}_{2} \mathrm{O}$ overlap, the air stream should be dried before analysis in order to prevent interference from water vapor. In operation of the IRGA for absolute analysis we used to pass the air stream through a tube of indicating Drierite $\left(\mathrm{CaSO}_{4}\right)$ before entry. Unfortunately use of a drying tube significantly increases the time constant in gas analysis. The drying tube has been replaced by a set of optical filters incorporated into the path of the infrared radia. tion stream. These filters transmit only radiation in the 3800 to $5700 \mathrm{~nm}$ wavelength band. Thus the main water vapor absorption bands are removed. Use of drying tubes is no longer required and the time constant of the system is substantially
reduced.

Air is moved into and through the laboratory under positive pressure. The entire system to the right of the pumps (PI.P8 in Fig. A.1) remains continuously under pressure. The analyzers themselves are under a slight positive pressure with $\mathrm{CO}_{2}$-free $\mathrm{N}_{3}$ gas. Therefore the possibility of contamination by $\mathrm{CO}_{\mathrm{g}}$-rich labotatory air has been effectively eliminated. After the automatic calibration procedure is completed the analyeer cells are purged with dry $\mathrm{N}_{\mathrm{a}}$

Temperatures of the gas samples entering the analyzer cells are monitored during both data and calibration cycles so that adjustments can be made for any significant difference in the temperature of ficld air simples and laboratory calibration gases,

Frequent calibrations are needed to avoid significant crrors caused by gas analyzer zero and span drift. Normally we use a $15 \mathrm{~min}$ record cycle although more frequent observations are possible. Automatic calibration is programmed once every hour. In addition, to further refine our $\mathrm{CO}_{2}$ gradient measurements, the 'zero-response' on the differential IRGA is obtained at the stant of every record cycle by passing a saimple of field air through both sides of the analyzer.

Computation of $\mathrm{CO}_{2}$ Flux. Rates of $\mathrm{CO}_{2}$ flux, $\mathrm{F}_{\mathrm{e}}$, to and from the ground are computed from the measured profiles of $\mathrm{CO}$. concentration ([CO $\left.\mathrm{CO}_{2}\right]$ ), wind speed and air temperature (Verma and Rosenberg, 1975 and 1976$)$ :

$$
\mathbf{F}_{\mathrm{c}}=\left[k^{2} \mathrm{z}^{2}\left(\frac{\partial U}{\partial z}\right)\left(\frac{\partial c}{\partial z}\right)\left(\phi_{\mathrm{m}}{ }^{-2}\right)\left(\frac{K c}{K m}\right)\right.
$$

where $\partial \mathrm{U} / \partial \mathrm{z}=$ wind speed gradient $=\mathrm{u}^{\bullet} / \mathrm{kz} \phi_{\mathrm{m}}$, with $\mathrm{u}^{\bullet}=$ friction velocity; $\phi_{\mathrm{m}}=$ nondimensional wind shear (or diabatic correction factor for the $\log$-law wind profile, $\partial U / \partial z=u \bullet / k z)$, $\mathrm{K}_{\mathrm{m}}=$ exchange coefficient for momentum, $\mathrm{K}_{r}=$ exchange coefficient for $\mathrm{CO}_{2}$ (assumed to be equal to the exchange efficient for water vapor, $\left.\mathrm{K}_{\mathrm{w}}\right), \partial \mathrm{c} / \partial \mathrm{z}=$ gradient of $\mathrm{CO}$ con centration, $k=$ von Karman's constant, $\vec{f}=$ conversion factor for CO. from ppm to specific weight, and $z=$ distance meas. uned in the vertical direction.

Both $\phi_{m}$ and $K_{w} / K_{m}$ have been found to vary with atmos. pheric thermal stability. Stability can be expressed in terms of the Richatson number (Ri) defincel ats $\mathrm{Ri}=g(j \theta / \partial t) \theta^{-1}$ $(j \mathrm{U} / \partial z)^{-2}$, where $\theta$ is the potential temperature; $g$ is the accelera. tion due to gravity: $\partial \mathrm{U} / \partial z$ and $\partial \theta / \partial z$ are the gradicnts of wind speed and potential temperature.

Stability correction formulate have beesl developed in recent anicrometeorological investigations. Those of Pruitt et al. (1973) ire used in our study of $\mathrm{CO}_{2}$ fluxes:

Moclel of Pruitu et al., 1973

(hereafter called the PML nodel)

$\phi_{w}=(1-16 \mathrm{Ri})^{-1 / 3}$ for unstable stratification,

$=(1+16 \mathrm{Ri})^{1 / 3}$ for stable stratification;

$\mathrm{K}_{w} / \mathrm{K}_{m}=1.13(1-60 \mathrm{Ri})^{0, v 7}$ for unstable stratificalion,

$k=0.42$
This model has been tested over an oat field against two other independent methods (namely the lysimetric and energy balance methods) for measuring C.O. flux. Results agreed willin Io to $12 \%$ on a short period batsis and within $51010 \%$ on a diail basis (for details, see Verma and Rosenberg, 1975). For some periods when daytime stability (advective inversions) were ob. served, the fluxes are computed assuming $\phi_{m}=1$ and $K_{w} / K_{m}$ $=1$.

Gradients (or derivatives with respect to height) of various profiles (c, $\mathrm{I}^{*}$, and $U$ ) were evaluated using finite differences in the manner suggested by panofsky (1965) If $\psi$ is a profile vatubble, then the gradient is given by:

$$
\frac{\partial \psi}{\partial z}=\frac{\psi_{2}-\psi_{1}}{\sqrt{z_{1}^{2} z_{2}} \ln \left(\frac{z_{2}}{z_{1}}\right)}
$$

where $z_{1}$ and $z_{2}$ are the heights above the ground. This approxi. mation is, of course, rigorous for logarithmic profjles, (Ising this approxiuntion equation (1) becomes:

$$
F_{\mathrm{c}}=f k^{2} \frac{\left(U_{2}-U_{1}\right)\left(c_{2}-c_{1}\right)}{\left(\ln \frac{z_{2}}{z_{i}}\right)^{2}}\left(\frac{K_{w}}{K_{m}}\right)\left(\phi_{m}{ }^{-2}\right)
$$

Measurements of $\left[\mathrm{CO}_{2}\right]$, wind speed, and air temperature matle at 5.6 and $16.0 \mathrm{~m}$ above the ground are used in equation (1). These elevations are selected so that, assuming fetch to licight ratios of 100 to 200, the $\mathrm{CO}_{2}$ flux computed should represent an integration of the region generally, rather than of the field in which the instrument mast stands.

\section{SOME INITIAL OBSERVATIONS}

$\mathrm{CO}_{2}$ Concentrations. Fig. 1 shows a set of typical daily $\mathrm{CO}_{2}$ concentration waves measured at $0.5,1.0$, 4.0 , and $16 \mathrm{~m}$ above ground. During the lall of 1972 the 2 ha experimental field in which the tower stands was planted to oats which reached a height of about $40 \mathrm{~cm}$. The surrounding area was planted to soybcans, alfalfa, and pasture grasses in commercial sized fields ranging from 5 to 50 ha. Some small areas of trees are also within the "fetch" of the tower.

With the onset of photosynthesis, immediately atter sumrise on each day, a sharp drawdown in $\mathrm{CO}_{\text {. }}$ con. centration occurred. Concentration at each clevation leveled off at about 10 hours (solar time) with only slight change until 16 hours. The morning transition from lapse profiles of $\mathrm{CO}_{2}(\partial \mathrm{C} / \partial \mathrm{z}<0$, or respiration conditions) to inversion profiles of $\mathrm{CO}_{2}(\partial \mathrm{C} / \partial \mathrm{L}>0$ or photosynthesis conditions) occurred first at the lower elevations. The change from lapse to inversion was usually sharp and abrupt. The return to at respirat. tion-type lapse profile in the afternoon is, typicilly, much less sharply defined. The shape of the diurnal $\mathrm{CO}_{2}$ concentration waves and the day to day variations depend primarily upon ambient light intensity and windspeed conditions.

There is considerably less diurnal variation in (:O). concentration at an elevation lar removed from llic crop canopy (e.g. $16 \mathrm{~m}$ ) as compared to an clevalion just above the canopy (e.g. $0.5 \mathrm{~m}$ ). Typically the amplitude of these $\mathrm{CO}_{2}$ concentration waves at $0.5 \mathrm{~m}$ wais about 2 to 4 times that at $16 \mathrm{~m}$.

CO. Flux. Figure 2 shows some typical daily jullterns of $\mathrm{CO}_{2}$ flux measured during the period June: to October 1973. The sign convention adopted herc

\footnotetext{
'Manufactured by Grubb Parsons and Co. Lul., Newcastle. upon Tyue, England. Spectral transmittance of these fileces is given in Janac (1971)

Panofsky, H. A. 1965. Reaualysis of Swinbanh's Kefare observations. Unpub. report, Peun. State Univ., Dep. of Ms tcorology, p. $66 \cdot 76$.
} 


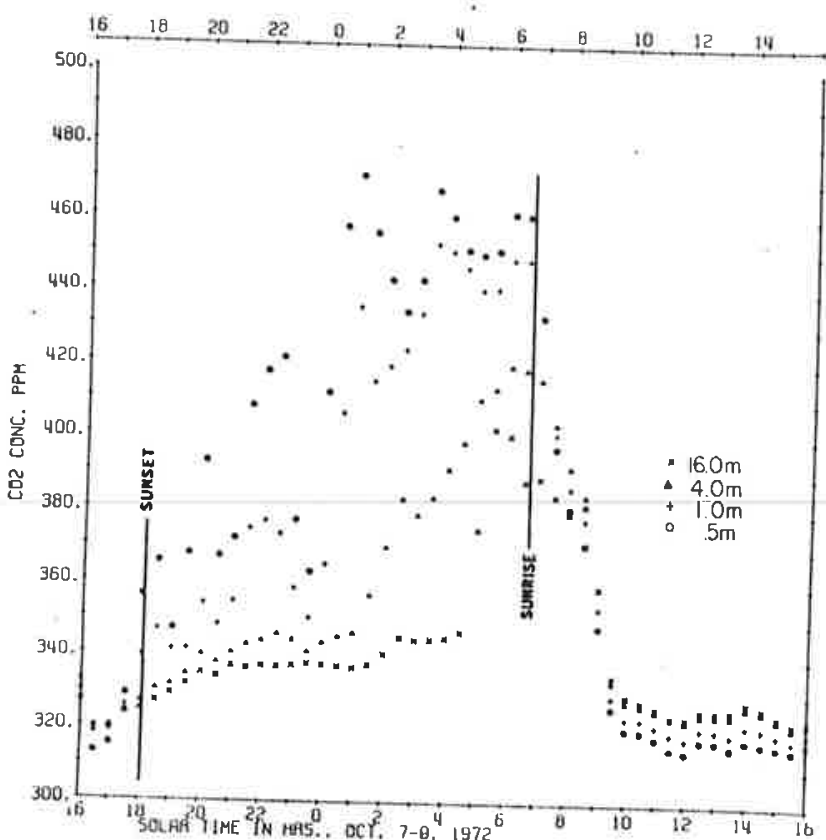
Fig. 1. Typical daily $\mathrm{CO}_{\mathrm{g}}$ concentration waves at different eleva-
tions, Mead, Neb.

gives $\mathrm{CO}_{2}$ flux toward the ground as positive and away from the ground as negative. Positive fluxes of $\mathrm{CO}_{2}$ from the air above to the photosynthesizing vegetation occur for 11 to 12 hours daily. The magnitudes of these fluxes depend, primarily, upon solar radiation, wind speed, and air temperature. Average radiation, wind speed, and air temperature for the days depicted in the figure are given in Table 1 . The peak daytime fluxes ranged from about 0.5 in early June to 1.5 or $2.0\left(\mathrm{~g} \times 10^{-7} \mathrm{~cm}^{-2} \mathrm{sec}^{-1}\right)$ in early August and 0.5 $\left(\mathrm{g} \times 10^{-7} \mathrm{~cm}^{-2} \mathrm{sec}^{-1}\right)$ in late September. Negative fluxes measured over the crop at night represent the sum of the soil and crop respiration which depends primarily on the soil and air temperature. Detailed results on $\mathrm{CO}_{2}$ fluxes are reported in Verma and Rosenberg (1976).

\section{ACKNOWLEDGMENTS}

This study was conducted with support of the Environmental Data Service, National Oceanic and Atmospheric Administra. E. Sandin, Rep. of Commerce, under Contract 2-35385. Mr. Dale was responsible for construction, contributed to the design and was responsible for construction of the system. Thanks are exNOAA, Boulder, Colo. for calibrating our primary standard gases.
Table 1. Solar energy receipts and mean daily temperature and windspeed on selected days during 1973 at Mead, Neb.

\begin{tabular}{|c|c|c|c|}
\hline Date & Solar radiation & $\begin{array}{c}\text { Mein windspeed } \\
\text { at } 5.6 \mathrm{~m} \\
\end{array}$ & $\begin{array}{c}\text { Mear air termperaturc } \\
\text { at } 5.6 \mathrm{~m} \\
\end{array}$ \\
\hline & ly day ${ }^{-1}$ & $\mathrm{~m} \mathrm{sec}^{-1}$ & C \\
\hline 10 June $197 \mathrm{y}$ & 718 & 6.68 & 25.9 \\
\hline 12 July 1973 & 712 & 4.83 & 27.3 \\
\hline 5 Aug. 1973 & 631 & 4.95 & 23.2 \\
\hline 18 Aчg. 1973 & $5 B 5$ & 4.06 & 25.3 \\
\hline 23 Sepl. 1973 & 247 & 3.73 & 16.6 \\
\hline
\end{tabular}

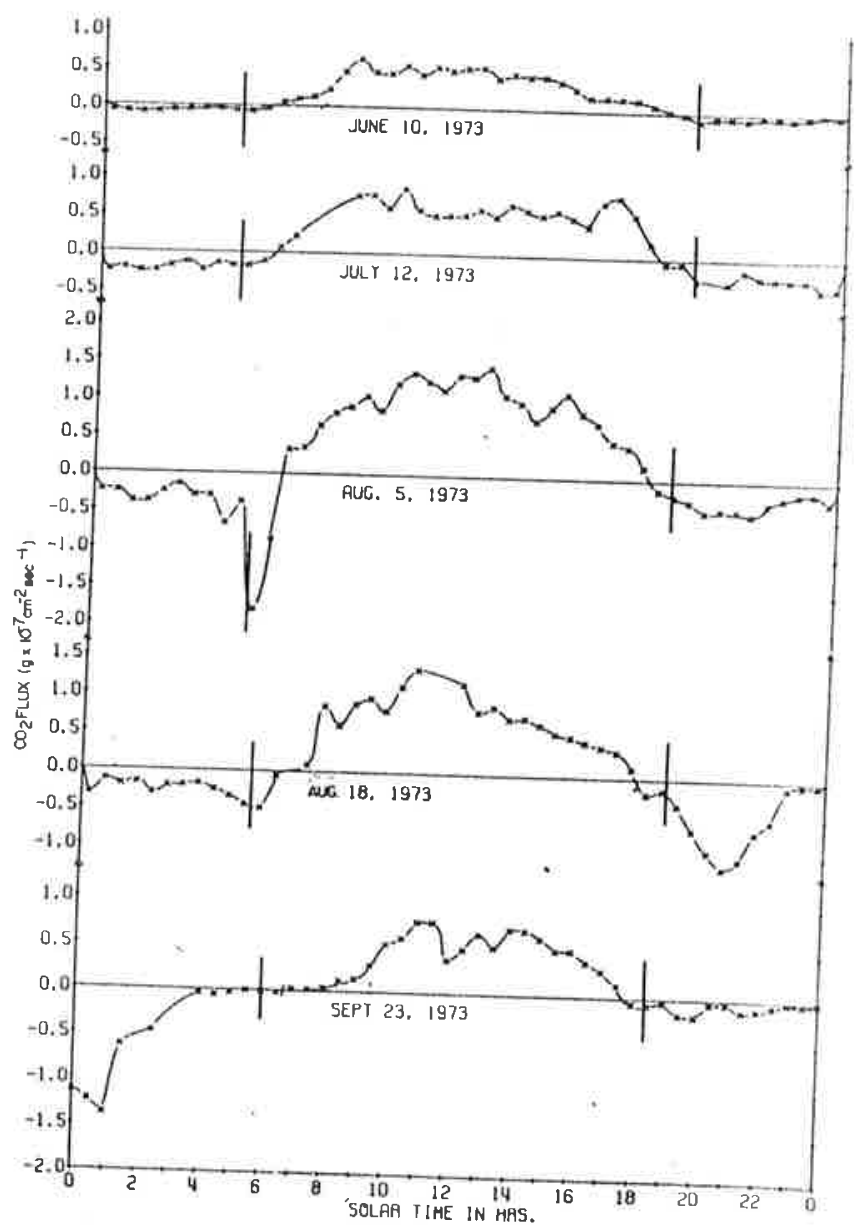

Fig. 2. Typical patterns of the diurnal flux of $\mathrm{CO}_{2}$ between 5.6 and $16.0 \mathrm{~m}$ during June to October 1973 at Mead, Neb. Sunrise and sunset times are indicated by the vertical lines.

\section{SUMMARY}

A program and the instrumentation regularly used to observe atmospheric carbon dioxide concentrations, gradients, and fluxes representative of a large agricultural region are described. Calibration procedures and errors ppm, whereas the absolute concentscussed. The accuracy of gradient measurements is generally close to \pm 0.2

The system for measurement of

IRGA output is recorded automatically concentration and gradients is programmed for automatic calibration. air temperature are also measured simultaneong every record and calibration cycle. Profiles of wind speed and fying influences of season and changing weasly for use in computing $\mathrm{CO}_{2}$ fluxes. In order to study the modiyear. 


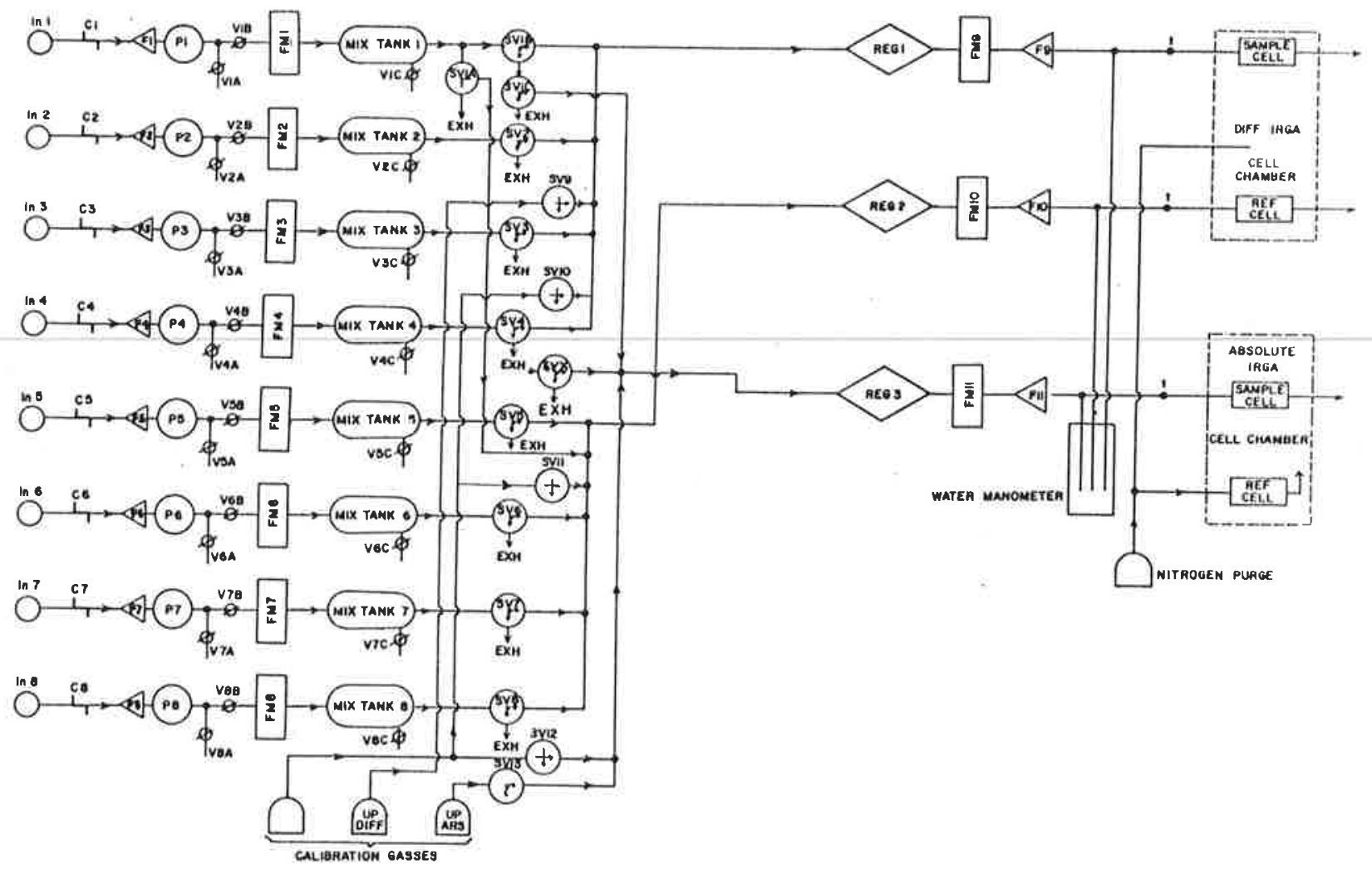
Fig. A.l. Appendix I. Detailed schematic of the $\mathrm{CO}_{2}$ sampling and analysis system used at the Univ. of Nebraska Micronteteorolugy
Laboratory.

\section{APPENDIX II \\ Component List \\ $\mathrm{CO}_{2}$ IRGA Flow and Control System (See Figure A.1)}

"In 1" through "In 8"

Filter (Gas flow), part no. 129712W, Model D\%-78006

MFR: Mine Safety Appliances, Pittsburgh, Penı.

Paper Filter Removed, replaced with 40 mesh stainless steel screen

Line between $\mathrm{Cl}$ through $\mathrm{C} 8$ and $\mathrm{Fl}$ through $\mathrm{F} 8$

Tubing bundle, Ten Tube, Polyethylene, $3 / 8$ " O.D. $\times .062^{\prime \prime}$

Wall. Part no. 1202-610

MFR: Samuel Moore \& Co.

9119 West Monroe

Houston, TX 77017

All other lines

1/8" I.D. Copper Tubing

Fl through F8

Air filter, Part no. S-103

MFR: Neplune Products, Inc.

353 East Blackwell St.

Dover, N.J. 07801

I'l through P8

Model 4K Neptune Dyna-Pump (Standard)

115 Vac. 60 Cycle

MFR: Neptune Products, Inc

353 East Blackwell St.

Dover, N.J. 07801

I.MI through FM8

Flowmelers, 0-5 LPM, Call. no. 520.23

MHR: Dwyer Instr. Iuc.

P.O. Bux 373

Michigan City, IN 46360
Mix Tanks 1 through 8

Surplus Air Force oxygen tanks, $280 \mathrm{cu}$. inches

SVIA through SV8 and SVX

Solenoid valves, 3 way, stainless steel, Cat, no. V53 DA 20:50 MFR: Skinner Electric Valve Co.

New Britain, Conn.

SV9 through SV13

Solenoid valves, 2 way, stainless steel

Cat. no. V52 DA 1052

MFR: Skinner Electric Valve Co. New Britain, Conn.

All other valves (V1B, V2A, V3C, etc.)

Common needle valves, $1 / 8$ " I.D.

Reg 1 through Reg 3

Differential regulator, Model H-21AT, 0-5 PSI range

MFR: ITT-Hammel-Dahl

175 Post Road

Warwick, R.I. 02888

li M9 through FMl

Flowmeter, 0.2-4.0 LPM Air, 4" scale

Cat, no. VFB-SSV-65-PF

MlR: Dwyer Instruments, Inc. P.O. Box 373 Michigan City, IN 46360

I9 through Fil

Guard filter, porous stainless steel elemeut, 5-9 micron Nominal Pore Size, Part no. 13541

MF R: Hoke, Inc., Cresskill, N.J.

Willer Mantornc:let

Outer 'lube: 2" I.D., Inner Tubes: 1/4" O.D., 1/8" I.I).

0-24 C.M with IMM Divisions

MlR: Univ, of Nelsraskil shop 


\section{COMMENTS}

The purpose of V1A, B\&C through V8A, B\&C is to enable nitrogen purging of the system, should moisture collect in the sample lines or mixing tanks. All tanks are mounted at an angle with the " $\mathrm{C}$ " valves attached at the lowest point. Purge can be accomplished by disconnecting lines at the pump, opening the " $\mathrm{A}$ " and " $\mathrm{C}$ " valves and applying nitrogen gas below valve "A".

Solenoid valves SV9 through SV11 are used for calibration of the analyzers and are controlled by an external timing system. Calibration is performed between normal recording cycles.

Absolute analysis is normally obtained by samples from line No. I through solenoid valves SVIB and SVIC. However absolute analysis of other lines may be obtained by connecting the input of solenoid valve SVX to the exhaust of other solenoid valves.

The sequence of sampling, both field samples and calibration gases, is controlled by patching pulses generated by the data logger. For example, line 1 can be compared with lines 5, 6 , or 7. Almost any combination can be obtained except that lines 1 through 4 cannot be compared against each other and the same holds true for lines 5 through 8 . However these lines may be re-routed to any input at any elevation or location, thereby permitting further flexibility in differential analysis.

\section{LITERATURE CITED}

Anonymous, 1972. Global environmental monitoring. SCOPE I. International Council of Scientific Unions. Scientific Connuit. tec on Problems of the Environment. Report submited to its United Nations Conference on the Human Environne'nt. Stockholnn.

Brown, K. W., and N. J. Rosenberg, 1968. Errors in sampling and infrared analysis of $\mathrm{CO}_{2}$ in air and their influence in le. termination of net photosynthetic rate. Agron. J. 60:309-311.

Janac, J. 1971. Infrared gas analyzers and other physical anal yzers. In $Z$. Sestak et al. (eds.). Plant photosynthetic production, manual of methorls. Dr. W. Junk N. V. The Higke.

Pruitt, W. O., D. L. Morgan, and F. J. Lourence. 1973. Momen. tum and mass transfer in the surface boundary layer, $Q$. J. $R$. Metcorol. Soc. 99:370-386.

Verma, S. B., and N. J. Rosenberg. 1975. Accuracy of lysimetric, energy balance, and stability-corrected actolynanic methods of estimating above-canopy flux of $\mathrm{CO}_{2 .}$ Agron. J 67:699-704.

-- , and --_ 1976. Carbon dioxide concentration and flux in a large agricultural region of the Great Plains of Ninti Anerica. J. Geophys. Res. 81:399-405. 